\title{
Effects of Toll-like receptor 9 and CpG oligodeoxynucleotides 1826 on sodium taurocholate-induced acute pancreatitis rats
}

\author{
LIANG SUN $^{1 *}$, YUANHUA LI $^{2 *}$, HUAYOU LUO $^{1 *}$, KUNHUA WANG $^{1}, \mathrm{LI} \mathrm{LI}^{3}$ and YUJIAN ZENG ${ }^{1 *}$ \\ Departments of ${ }^{1}$ Gastrointestinal Surgery and ${ }^{2}$ Anesthesiology, The First Affiliated Hospital of Kunming Medical University, \\ Kunming, Yunnan 650031; ${ }^{3}$ Department of Hepatobiliary Surgery, The Affiliated Ganmei Hospital \\ of Kunming Medical University, Kunming, Yunnan 650011, P.R. China
}

Received August 31, 2016; Accepted May 25, 2017

DOI: $10.3892 / \mathrm{mmr} .2018 .9346$

\begin{abstract}
The aim of the present study was to investigate the effects of Toll-like receptor (TLR) 9 and CpG oligodeoxynucleotide (CpG-ODN)1826 on sodium taurocholate-induced acute pancreatitis (AP) rats at different time points. Pathological examination indicated that the severity of pancreatic tissue damage following AP increased with time. Additionally, TLR9 protein levels were upregulated after AP, and were higher at $6 \mathrm{~h}$ compared with at $3 \mathrm{~h}$. Subsequently, the TLR9 protein levels were downregulated at $12 \mathrm{~h}$, but remained higher than the control group. In rats subjected to AP, tumor necrosis factor (TNF- $\alpha$ protein expression levels and serum amylase (AMS) in the serum were increased until $12 \mathrm{~h}$. The expression level of TNF- $\alpha$ protein in the AP $12 \mathrm{~h}$ group was higher than that in the AP 3 and $6 \mathrm{~h}$ groups. In addition, following CpG-ODN1826 administration, the morphology of pancreatic tissue appeared worse compared with that in the AP only groups. Furthermore, CpG-ODN1826 administration induced an increase in TLR9 expression levels compared with the AP alone group at 0,3, 6 and $12 \mathrm{~h}$. TNF- $\alpha$ in the $\mathrm{CpG}+\mathrm{AP} 12 \mathrm{~h}$ group was upregulated compared with that in the $\mathrm{CpG}+\mathrm{AP} 3$ and $6 \mathrm{~h}$ groups; however, no change was observed between 3 and $6 \mathrm{~h}$. Thus, these data indicate that CpG-ODN1826 aggravates sodium taurocholate-induced pancreas damage in rats.
\end{abstract}

Correspondence to: Professor Yujian Zeng or Dr Huayou Luo, Department of Gastrointestinal Surgery, The First Affiliated Hospital of Kunming Medical University, 295 Xi Chang Road, Kunming, Yunnan 650031, P.R. China

E-mail: zengyujian2010@163.com

E-mail: 1677546296@qq.com

*Contributed equally

Key words: acute pancreatitis, Toll-like receptor 9, CpG oligodeoxynucleotide 1826 , tumor necrosis factor- $\alpha$, serum amylase

\section{Introduction}

Acute pancreatitis (AP) is an inflammatory disease of the pancreas, which is characteristically sterile and results in acinar cell necrosis. In its most severe form, AP is associated with multi-organ failure and mortality $(1,2)$. The overproduction of various cytokines and non-cytokine inflammatory mediators may account for AP systemic manifestations, such as tumor necrosis factor (TNF)- $\alpha$ (3). Inflammatory mediator, TNF- $\alpha$ was upregulated in the serum of patients with severe AP and was an effective discriminator of AP severity (4).

Toll-like receptor (TLR) signaling pathways exert essential proinflammatory activities in AP (5). TLRs form a major group of damage-associated molecular pattern receptors. Among the TLRs, TLR9 is the only receptor for detecting DNA (self and non-self). Hence, DNA released from damaged cells triggers inflammation via TLR9 in immune cells (6). TLR9 is expressed in the rat pancreas and is involved in cerulein-induced pancreatitis (7). CpG oligodeoxynucleotide (CpG-ODN) is a short ( $20 \mathrm{bp})$, single-stranded synthetic DNA fragment containing the immunostimulatory $\mathrm{CpG}$ motif, a potent TLR9 agonist, which activates dendritic cells (DCs) and B cells to produce type I interferons and inflammatory cytokines (8). Bacterial and viral genomic DNA containing the $\mathrm{CpG}$ motif (CpG-DNA) and its analog, oligodeoxynucleotide-containing $\mathrm{CpG}$ motif (CpG-ODNs) are powerful activators of the innate immune system (8).

To the best of our knowledge, the effect of CpG-ODN1826 on sodium taurocholate-induced pancreas damage in rats at different points in time has yet to be reported. In the present study, the aim was to investigate the temporal differences in the expression levels of TLR9 and early-stage inflammatory cytokines (TNF- $\alpha$ ) in rats subjected to AP, and to determine the role of TLR9 in AP from edema to necrosis. In the present study, AP and CpG + AP animal models were established in Sprague Dawley (SD) rats over time periods of 0 to $12 \mathrm{~h}$. Pathological changes were observed by hematoxylin and eosin (H\&E) staining and TLR9 protein expression levels in the pancreas were detected by western blotting. Serum TNF- $\alpha$ protein levels were detected by enzyme linked immunosorbent assay (ELISA). In addition, AMS was assessed using 
an amylase activity kit. The present study may provide the optimal therapeutic time points and methods to prevent the progression from edema to cell death during AP.

\section{Materials and methods}

Animals and treatments. A total of 104 adult male SD rats (weight at the start of the experiments, 220 $20 \mathrm{~g}$ ) provided by Kunming Medical University (Kunming, China) animal center were employed in the current study. Rats were housed in a temperature of $25 \pm 1.0^{\circ} \mathrm{C}$ and a humidity of $\sim 50 \%$, under a 12-h light/dark cycle, with food and water provided ad libitum. Experiments were conducted according to the guidelines for the care and use of experimental animals established by the Ministry of Science and Technology of the People's Republic of China (approval no. 2006-398), and was approved by the Laboratory Animal Management Committee of Kunming Medical University. All efforts were made to minimize animal stress/distress. SD rats were randomly divided into eight groups as presented in Table I.

Animal models. Prior to the experiment, the rats were fasted for $24 \mathrm{~h}$ with free access to water. They were anesthetized by intraperitoneal injection $(0.5 \mathrm{ml} / 100 \mathrm{~g})$ with $7 \%$ chloral hydrate. According to $\mathrm{Yu}$ et al (9), the ventral midline was incised for entry into the abdominal cavity to expose the general bile duct and the pancreatic duct. The biliopancreatic duct was occluded with a vascular clip for entry to the distal duodenum. The animals in the experimental group were infused slowly $(3 \mathrm{ml} / \mathrm{h})$ with $5 \%$ sodium taurocholate $(0.1 \mathrm{ml} / 100 \mathrm{~g}$; Sigma-Aldrich, Merck KGaA, Darmstadt, Germany) using four pediatric scalp acupuncture needles at the proximal end. The control group was infused with the equivalent quantity of normal saline. To prevent large quantities of drug reflux, the needle was not removed for $10 \mathrm{~min}$ after the injection. After modeling, the rat skin was disinfected and the peritoneum was closed using a continuous single-layer suture, while the rest was closed using a full-layer simple-interval suture. Subsequent to closing the abdomen, the rats were injected with $5 \mathrm{ml}$ saline in the inside position of the lower limb muscle to restore the water lost during surgery. In addition, in order to investigate the role of TLR9, CpG-OND1826 (3'-tccatgacg ttcctgacgtt-'5) was synthesized by Sangon Biotech Co., Ltd. (Shanghai, China) and injected into the enterocoelia $(1 \mu \mathrm{g} / \mu \mathrm{l}$; $200 \mu \mathrm{l})$ prior to establishing the AP model.

Tissue preparation. For all experiments, animals were deeply anesthetized with $7 \%$ chloral hydrate $(0.5 \mathrm{ml} / 100 \mathrm{~g}$ body weight). Blood samples $(1.5 \mathrm{ml})$ were collected via abdominal aorta puncture under anesthesia. All blood samples were centrifuged at $100 \times \mathrm{g}$ for $5 \mathrm{~min}$ at $37^{\circ} \mathrm{C}$ and the supernatant fluid (serum) was collected, aliquoted and stored at $-20^{\circ} \mathrm{C}$ for the ELISA and AMS tests. The pancreas was removed and divided into two segments. One segment was stored at $-80^{\circ} \mathrm{C}$ for western blot analysis. For subsequent pathological examination and immunohistochemistry, the other part was fixed with $10 \%$ paraformaldehyde at room temperature for $4 \mathrm{~h}$.

$H \&$ Estaining. The pancreas samples were fixed in formalin and embedded in paraffin routinely, as described by Han et al (10).
The paraffin blocks were sliced into continuous 5- $\mu \mathrm{m}$ sections. The sections were dewaxed with xylene, and washed with ethanol and water. The sections were stained with hematoxylin (Beijing Solarbio Science \& Technology Co., Ltd., Beijing, China) at room temperature for $5 \mathrm{~min}$, differentiated, washed, stained with eosin (Beijing Solarbio Science \& Technology Co., Ltd.) at room temperature for $2 \mathrm{~min}$, dehydrated with graded ethanol and cleared with xylene. Then, the sections were mounted onto slides and observed under an Olympus BH-2 microscope (Olympus Corporation, Tokyo, Japan); images were captured using the image acquisition system of the microscope. The total surface of the slides was scored by two pathologists, blinded to the experimental conditions and with expertise in pancreatic pathology, for edema, acinar necrosis, hemorrhage and fat necrosis, inflammation and perivascular infiltrate, according to Schmidt et al (11), to determine the severity of injury.

Western blot analysis. In order to determine TLR9 protein expression levels, pancreatic tissues were lysed and homogenized in radioimmunoprecipitation assay lysis buffer (Beyotime Institute of Biotechnology, Haimen, China) including protease inhibitor cocktail (Roche Diagnostics GmbH, Mannheim, Germany). Equal amounts $(100 \mu \mathrm{g})$ of extracted protein samples were resolved by $15 \%$ SDS-PAGE, using electrophoresis buffer (24.8 $\mathrm{mM}$ Tris, $192 \mathrm{mM}$ glycine and $0.1 \%$ SDS ) at $60 \mathrm{~V}$ for $30 \mathrm{~min}$ and $100 \mathrm{~V}$ for $1.5 \mathrm{~h}$. The precipitated proteins were separated and transferred to polyvinylidene difluoride membranes at $350 \mathrm{~mA}$ for $4 \mathrm{~h}$, using transfer buffer $(24.8 \mathrm{mM}$ Tris, $192 \mathrm{mM}$ glycine and $10 \%$ methanol). After blocking with $5 \%$ nonfat milk in TBS containing 3\% Tween-20 for $1 \mathrm{~h}$ at room temperature, the membranes were incubated with rabbit polyclonal anti-TLR 9 antibody (cat. no. ab37154; dilution 1:2,500; Abcam, Cambridge, MA, USA) or rabbit polyclonal anti-GAPDH antibody (cat. no. ab37168; dilution 1:5,000; Abcam) in TBS overnight at $4^{\circ} \mathrm{C}$. The membranes were rinsed 4 times in TBST prior to incubation at $37^{\circ} \mathrm{C}$ for $1.5 \mathrm{~h}$ with anti-rabbit secondary antibody (cat. no. SAB3700840; dilution 1:5,000; Sigma-Aldrich; Merck KGaA). Subsequently, the membranes were rinsed in TBST 4 times and protein bands were visualized by enhanced chemiluminescence using SuperSignal West Pico Chemiluminescent substrate (Pierce; Thermo Fisher Scientific, Inc., Waltham, MA, USA). Blots were semi-quantified by densitometry using Image-Pro Plus software version 6.0 (Media Cybernetics, Inc., Rockville, MD, USA).

Immunohistochemistry (IHC). According to the method of Sholl et al (12), TLR9 IHC was performed on $8 \mu$ m-thick formalin-fixed paraffin-embedded tissue sections. Slides were baked at $37^{\circ} \mathrm{C}$ in a constant temperature drying oven, deparaffinized in xylene, dehydrated through graded alcohols, and subjected to antigen retrieval with $0.01 \mathrm{M}$ citrate buffer ( $\mathrm{pH}$ 6.0) in a microwave oven at $98^{\circ} \mathrm{C}$ for $15 \mathrm{~min}$. All further steps were performed at room temperature in a hydrated chamber. Slides were pretreated with $3 \% \mathrm{H}_{2} \mathrm{O}_{2}$ (Sinopharm Chemical Reagent Co., Ltd., Shanghai, China) for $15 \mathrm{~min}$ to quench endogenous peroxidase activity, and washed in $50 \mathrm{mM}$ Tris- $\mathrm{Cl}$ (pH 7.4). Slides were blocked using 5\% normal goat serum (Gibco; Thermo Fisher Scientific, Inc.), and subsequently incubated with rabbit anti-TLR 9 antibody (dilution, 1:300) overnight 
Table I. Grouping and treatment of Sprague-Dawley rats.

\begin{tabular}{lcc}
\hline Group & $\begin{array}{c}\text { H\&E staining/ } \\
\text { H\&E score }\end{array}$ & $\begin{array}{r}\text { Western blotting/ELISA/ } \\
\text { serum amylase tests }\end{array}$ \\
\hline Control & $\mathrm{n}=5$ & $\mathrm{n}=8$ \\
AP 3 h & $\mathrm{n}=5$ & $\mathrm{n}=8$ \\
AP 6 h & $\mathrm{n}=5$ & $\mathrm{n}=8$ \\
AP 12 h & $\mathrm{n}=5$ & $\mathrm{n}=8$ \\
CpG & $\mathrm{n}=5$ & $\mathrm{n}=8$ \\
CpG + AP 3 h & $\mathrm{n}=5$ & $\mathrm{n}=8$ \\
CpG + AP 6 h & $\mathrm{n}=5$ & $\mathrm{n}=8$ \\
CpG + AP 12 h & $\mathrm{n}=5$ & $\mathrm{n}=8$ \\
\hline
\end{tabular}

H\&E, hematoxylin and eosin.

at $4^{\circ} \mathrm{C}$. Slides were washed with TBS and incubated at $37^{\circ} \mathrm{C}$ with the ImmPRESS ${ }^{\text {TM }}$ Reagent anti-rabbit immunoglobulin (Ig) G secondary antibody (dilution, 1:250; cat. no. MP-7401; Vector Laboratories, Inc., Burlingame, CA, USA) for $2 \mathrm{~h}$. The slides were rinsed with TBS five times, each for $5 \mathrm{~min}$. Finally, the sections were visualized by $0.05 \%$ DAB staining (Beyotime Institute of Biotechnology). A negative control was created by replacing the primary antibody with $2 \%$ goat serum to ascertain the specificity of antibody staining. Immunoreactive products were observed and photographed under a light microscope (Leica Microsystems GmbH, Wetzlar, Germany) coupled with a computer-assisted video camera.

Detection of serum inflammatory cytokines by ELISA. Anti-TNF- $\alpha$ (cat. no. 70-EK3822/2; Multisciences Lianke Biotech, Co., Ltd., Hangzhou China) IgG autoantibody titers were measured using commercially available ELISA kits according to the manufacturer's instructions. Serum samples were diluted to 1:20 in assay diluent. Diluted serum samples were added to 96-well plates. Subsequent to rinsing off any unbound substances, peroxidase-conjugated goat polyclonal anti-rat IgG antibodies included in the kit were added to the wells. Development was performed using a microplate reader set to $450 \mathrm{~nm}$ to reflect the level of anti-TNF- $\alpha$ autoantibodies bound in the initial step for each sample.

ELISA quantification. To compare results from different plates, test sample ODs were adjusted relative to the positive and negative control samples supplied in each kit. The mean OD of duplicate wells was calculated. The index value of each tested serum was defined by the following formula: Inde $x=(O D$ of tested serum-OD of negative control $) /(O D$ of positive control-OD of negative control)x100. A cutoff ELISA value of $9 \mathrm{U} / \mathrm{ml}$ was used (where $\geq 9.0 \mathrm{U} / \mathrm{ml}$ represents a positive result) according to the manufacturer's instructions.

Pancreatic amylase test. Measurement of serum or ascites pancreatic amylase was performed according to the instructions of the amylase test kit (cat. no. TE0203-200T; Beijing Leagene Biotechnology Co., Ltd., Beijing China). Samples were diluted 1:20 in normal saline. The diluted samples $(3 \mu \mathrm{l})$ were added to the wells with $37.5 \mu \mathrm{l}$ AMS assay buffer, mixed, and incubated in $37^{\circ} \mathrm{C}$ for $7.5 \mathrm{~min}$. Subsequently, $37.5 \mu \mathrm{KI}$ working solution and $225 \mu \mathrm{l}$ distilled water were added. For the blank control, $3 \mu \mathrm{l}$ distilled water was used instead of the samples. Development was performed using a microplate reader set to $660 \mathrm{~nm}$. The blank control was set as 0 , and the OD was read for the samples and the blank control. The following calculation was performed: Sample AMS activity $(\mathrm{U} / \mathrm{dl})=[($ blank control-sample $) /($ blank control x80)x20].

Statistical analysis. Data are presented as the mean \pm standard deviation of 3 independent experiments. The statistical significance of the differences between groups was assessed using independent samples Student's t-test for pair-wise comparisons or one-way analysis of variance followed by a post hoc lest significant difference or Games-Howell test for multiple comparisons. Statistical analysis was performed using SPSS software version 17.0 (SPSS, Inc., Chicago, IL, USA). $\mathrm{P}<0.05$ was considered to indicate a statistically significant difference.

\section{Results}

Pathological examination. The pancreas samples in the control rats were normal (Fig. 1A). In the AP $3 \mathrm{~h}$ group, the tissue samples exhibited a mild edema and red blood cells (RBCs) were observed (Fig. 1B). In the AP $6 \mathrm{~h}$ group, certain pancreas samples exhibited edema. Furthermore, certain cells were degenerated and a greater number of RBCs were observed when compared with that in the AP 3 h group (Fig. 1C). In the AP $12 \mathrm{~h}$ group, the pancreas samples exhibited hemorrhages, pancreatic cell degeneration and necrosis (Fig. 1D). Subsequent to the $\mathrm{CpG}-\mathrm{OND} 1826$ injection, in the AP $0 \mathrm{~h}(\mathrm{CpG})$ group, the tissue samples were normal (Fig. 1E). However, the morphological structure of the tissue samples was worse than that of the tissue samples from the CpG-OND1826-treated animals at $3 \mathrm{~h}$ (Fig. 1F), 6 h (Fig. 1G) and 12 h (Fig. 1H).

The H\&E score was higher in the AP $3 \mathrm{~h}, 6 \mathrm{~h}$ and $12 \mathrm{~h}$ groups when compared with that in the control group (Fig. 1I; all $\mathrm{P}<0.05)$. Furthermore, the score was greater in the AP $6 \mathrm{~h}$ $(\mathrm{P}<0.05)$ and $12 \mathrm{~h}(\mathrm{P}<0.05)$ groups compared with that in the AP $3 \mathrm{~h}$ group, and it increased further at $12 \mathrm{~h}(\mathrm{P}<0.05$; Fig. 1I). Additionally, the H\&E score was greater in the $\mathrm{CpG}+\mathrm{AP} 3$, 6 and $12 \mathrm{~h}$ groups $(\mathrm{P}<0.01$ for all $)$ compared with that in the CpG group (Fig. 1J). In addition, the score was increased in the $\mathrm{CpG}+\mathrm{AP} 3$ (Fig. 1K), 6 (Fig. 1L) and $12 \mathrm{~h}$ (Fig. 1M) groups when compared with that in the CpG-OND1826 untreated groups $(\mathrm{P}<0.05$ for all). However, no significant difference was identified between the $\mathrm{CpG}$ and control groups $(\mathrm{P}>0.05)$.

Temporal differences in TLR 9 protein expression in the AP and $C p G+A P$ groups. The levels of TLR 9 protein expression are presented in Fig. 2. TLR9 protein was expressed in pancreatic cells (Fig. 2B). The levels of TLR 9 protein expression were upregulated in the AP 3, 6 and $12 \mathrm{~h}$ groups when compared with those in the control group (Fig. 2A and D; $\mathrm{P}<0.05)$. Additionally, TLR9 expression levels were upregulated in the AP $6 \mathrm{~h}$ group compared with those in the AP 3 and $12 \mathrm{~h}$ groups $(\mathrm{P}<0.05$; Fig. $2 \mathrm{~A}$ and $\mathrm{D})$. However, no difference in TLR9 expression levels was identified between the AP 6 and $12 \mathrm{~h}$ groups ( $\mathrm{P}>0.05$; Fig. $2 \mathrm{~A}$ and $\mathrm{D})$. Following CpG-OND 


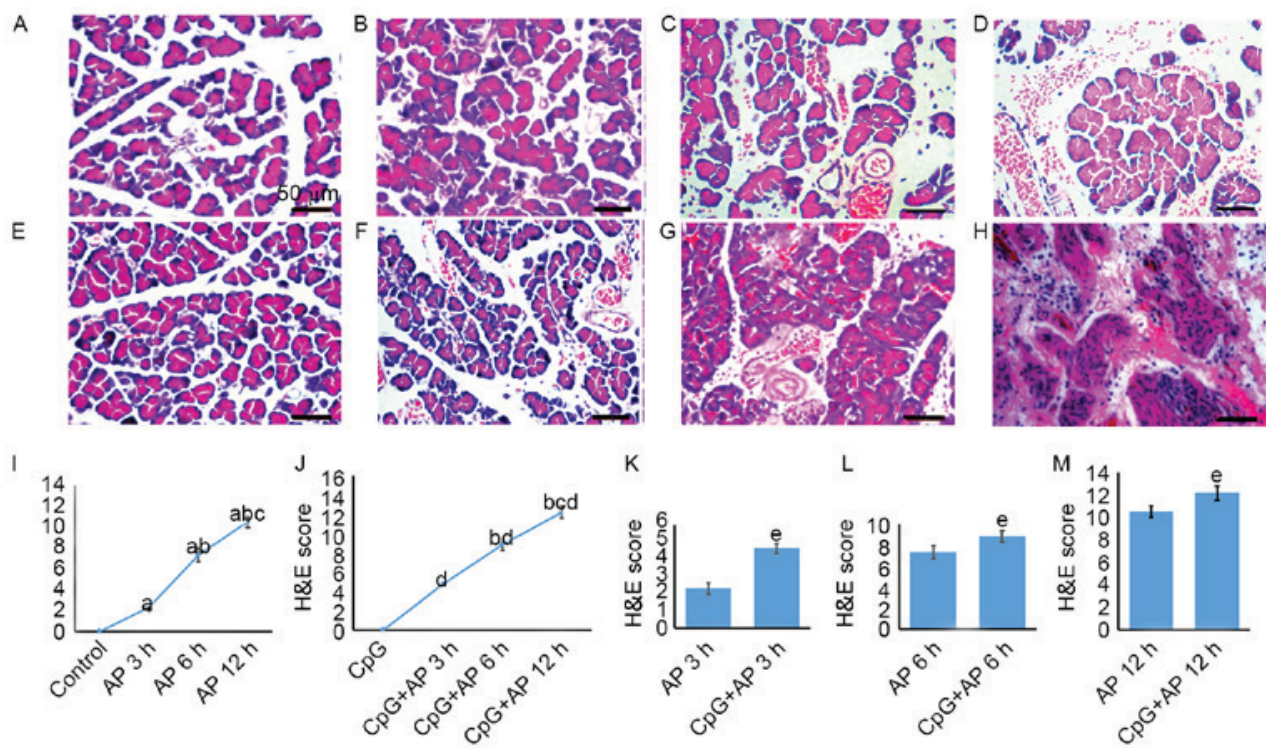

Figure 1. H\&E staining and scoring. H\&E staining of the (A) control group, (B) AP 3 h group, (C) AP 6 h group, (D) AP 12 h group, (E) CpG group, (F) $\mathrm{CpG}+\mathrm{AP} 3 \mathrm{~h}$ group, (G) $\mathrm{CpG}+\mathrm{AP} 6 \mathrm{~h}$ group and the $(\mathrm{H}) \mathrm{CpG}+\mathrm{AP} 12 \mathrm{~h}$ group. Scale bar, $50 \mu \mathrm{m}$. H\&E scores of the (I) control, and AP 3,6 and $12 \mathrm{~h}$ groups; (J) CpG, and $\mathrm{CpG}+\mathrm{AP} 3,6$ and $12 \mathrm{~h}$ groups; (K) $\mathrm{AP} 3 \mathrm{~h}$ and $\mathrm{CpG}+\mathrm{AP} 3 \mathrm{~h}$ groups; (L) AP $6 \mathrm{~h}$ and $\mathrm{CpG}+\mathrm{AP} 6 \mathrm{~h}$ groups; (M) $\mathrm{AP} 12 \mathrm{~h}$ and $\mathrm{CpG}+\mathrm{AP}$ $12 \mathrm{~h}$ groups. ${ }^{a} \mathrm{P}<0.05$ vs. control group; ${ }^{\mathrm{b}} \mathrm{P}<0.05$ vs. $3 \mathrm{~h}$ group; ${ }^{\mathrm{c}} \mathrm{P}<0.05$ vs. $6 \mathrm{~h}$ group; ${ }^{\mathrm{d}} \mathrm{P}<0.05$ vs. $\mathrm{CpG}$ group; ${ }^{\mathrm{P}}<0.05$ vs. AP group. $\mathrm{H} \& \mathrm{E}$, hematoxylin and eosin; AP, acute pancreatitis.

A

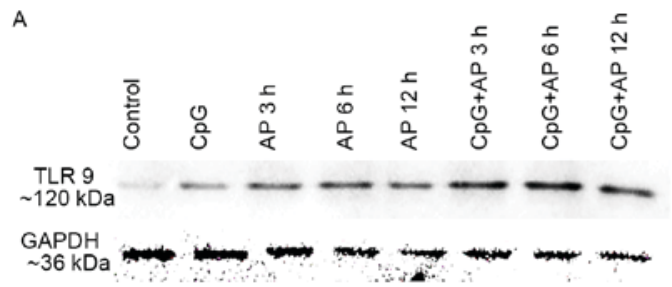

C

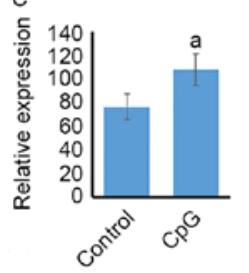

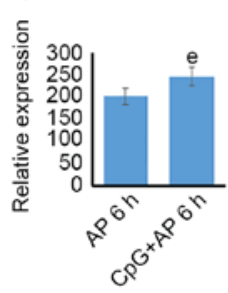
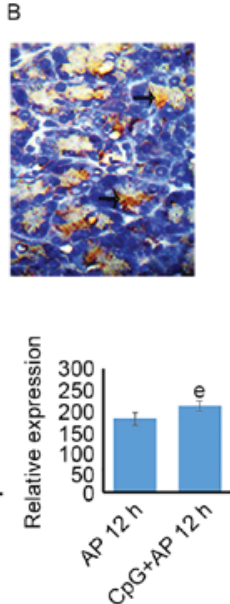

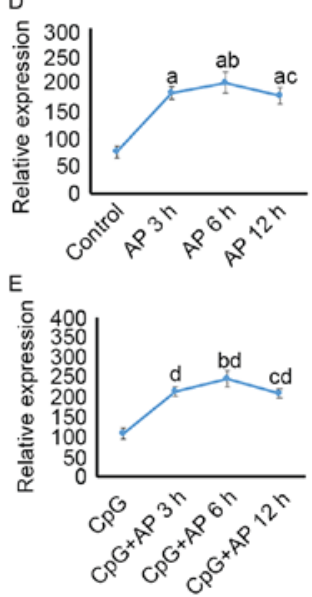

Figure 2. TLR9 protein expression levels in pancreatic tissue samples at different time points. (A) Protein bands from western blot analysis. (B) TLR9 protein expression levels in pancreatic tissue samples as assessed by immunohistochemistry (magnification, x400). (C) Quantification of TLR9 expression levels (by independent samples t-test). (D) Quantification of TLR9 expression levels among the (D) control, and AP 3,6 and 12 h groups and (E) CpG, CpG + AP 3, 6 and $12 \mathrm{~h}$ groups (comparisons among different time points were analyzed using one-way ANOVA). ${ }^{\mathrm{a}} \mathrm{P}<0.05 \mathrm{vs}$. control group; ${ }^{\mathrm{b}} \mathrm{P}<0.05 \mathrm{vs} .3 \mathrm{~h}$ group; ${ }^{\mathrm{c}} \mathrm{P}<0.05$ vs. 6 h group; ${ }^{\mathrm{d}} \mathrm{P}<0.05$ vs. $\mathrm{CpG}$ group; ${ }^{\mathrm{e}} \mathrm{P}<0.05$ vs. AP group. TLR9, Toll-like receptor 9; AP, acute pancreatitis.

injection, the expression level of TLR9 was upregulated when compared with that in the AP 0 (control), 3, 6 and $12 \mathrm{~h}$ groups $(\mathrm{P}<0.05$ for all; Fig. 2A and $\mathrm{C})$. The levels of TLR9 protein expression were upregulated in the $\mathrm{CpG}+\mathrm{AP} 3,6$ and $12 \mathrm{~h}$ groups $(\mathrm{P}<0.01$ for all) compared with that in the $\mathrm{CpG}$ group (Fig. 2A and E). Furthermore, TLR9 expression levels in $\mathrm{CpG}+\mathrm{AP} 6 \mathrm{~h}$ group was higher than that in the $\mathrm{CpG}+\mathrm{AP} 3$ and $12 \mathrm{~h}(\mathrm{P}<0.05$; Fig. 2A and $\mathrm{E})$.

Temporal differences in serum TNF- $\alpha$ protein expression levels. TNF- $\alpha$ protein expression was upregulated in the AP 3, 6, and $12 \mathrm{~h}$ groups $(\mathrm{P}<0.05$ for all) compared with that in the control group (Fig. 3A). Additionally, the level of TNF- $\alpha$ protein expression was higher in the $12 \mathrm{~h}$ group than in the AP
3 and 6 h groups $(\mathrm{P}<0.05$; Fig. 3A). However, no significant difference was identified between the AP 3 and $6 \mathrm{~h}$ groups (P>0.05; Fig. 3A). TNF- $\alpha$ expression levels in the CpG + AP 3, $6,12 \mathrm{~h}$ group were increased when compared with those in the CpG group $(\mathrm{P}<0.05$ for all; Fig. $3 \mathrm{~B})$. However, no significant difference was identified between the $\mathrm{CpG}+\mathrm{AP} 3$ and $6 \mathrm{~h}$ ( $\mathrm{P}>0.05$; Fig. 3B). In addition, $\mathrm{CpG}-\mathrm{OND} 1826$ administration caused upregulation of $\mathrm{TNF}-\alpha$ protein expression when compared with that in the AP 0 (control; Fig. 3C), 3 (Fig. 3D), 6 (Fig. 3E), and $12 \mathrm{~h}$ groups (Fig. 3F; $\mathrm{P}<0.05$ for all).

Temporal differences in serum AMS. AMS was upregulated in the AP 3, 6, and $12 \mathrm{~h}$ groups $(\mathrm{P}<0.01$ for all) compared with that in the control group (Fig. 4A). However, no significant 
A
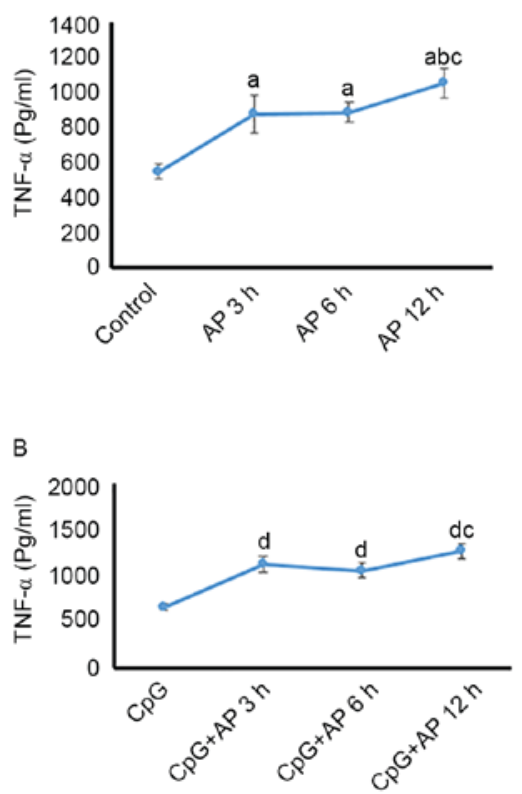

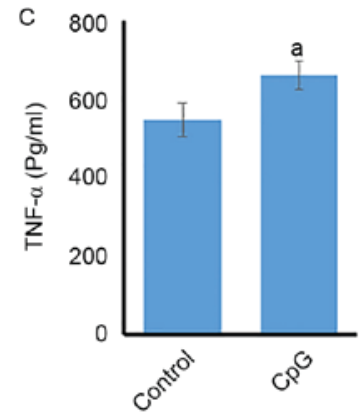

D
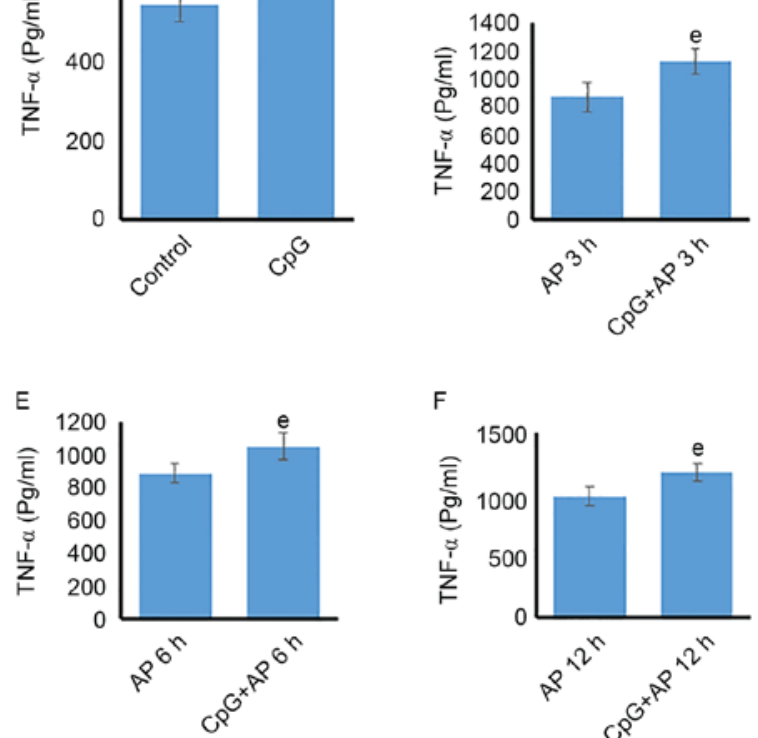

F

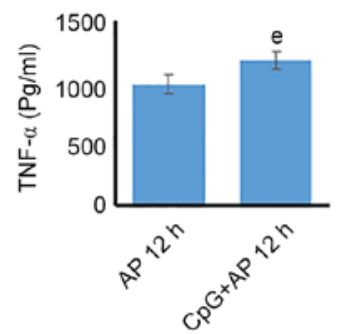

Figure 3. Serum TNF- $\alpha$ protein expression levels in pancreatic tissue samples at different time points. TNF- $\alpha$ protein expression levels in the (A) AP and (B) $\mathrm{CpG}+\mathrm{AP}$ groups at different time points. Comparisons among different time points were analyzed using one-way ANOVA. TNF- $\alpha$ expression levels in the (C) control and $\mathrm{CpG}$ groups, (D) AP $3 \mathrm{~h}$ and $\mathrm{CpG}+\mathrm{AP} 3 \mathrm{~h}$ groups, (E) AP $6 \mathrm{~h}$ and $\mathrm{CpG}+\mathrm{AP} 6 \mathrm{~h}$ groups and (F) AP $12 \mathrm{~h}$ and $\mathrm{CpG}+\mathrm{AP} 12 \mathrm{~h}$ groups. Independent samples t-test was used for comparisons between two groups. ${ }^{a} \mathrm{P}<0.05$ vs. control group; ${ }^{b} \mathrm{P}<0.05$ vs. $3 \mathrm{~h}$ group; ${ }^{\mathrm{c}} \mathrm{P}<0.05$ vs. $6 \mathrm{~h}$ group; ${ }^{\mathrm{d}} \mathrm{P}<0.05$ vs. $\mathrm{CpG}$ group; ${ }^{\mathrm{e}} \mathrm{P}<0.05$ vs. AP group. TNF, tumor necrosis factor; $\mathrm{AP}$, acute pancreatitis.
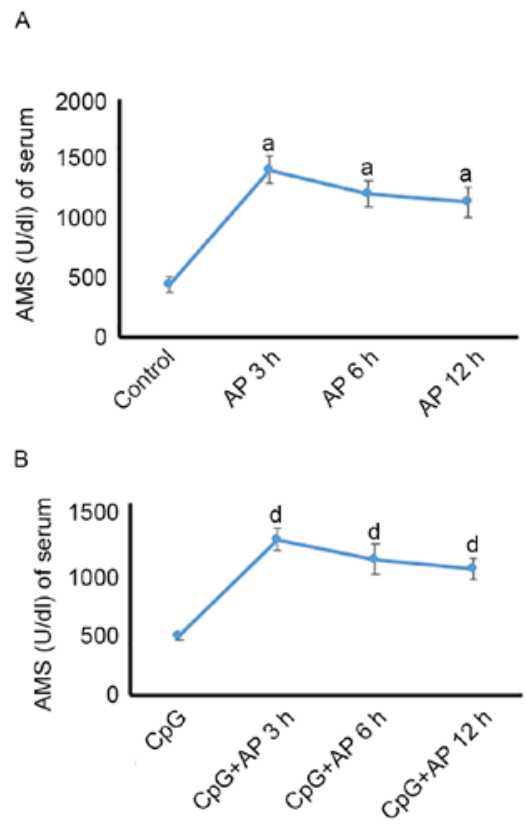
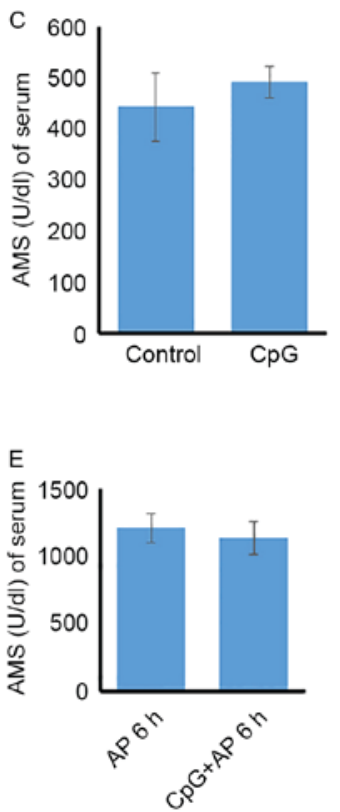
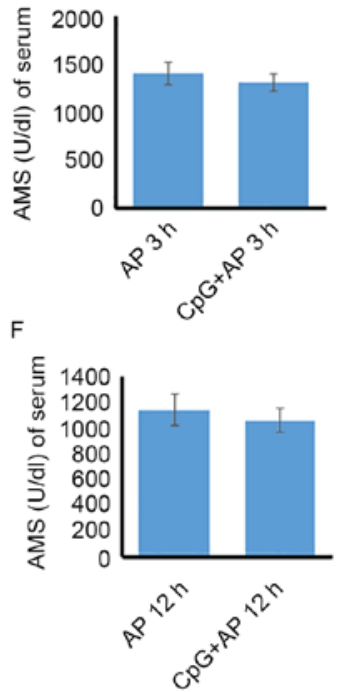

Figure 4. Temporal differences in serum AMS. Serum AMS in the (A) AP group at and (B) CpG + AP group at different time points. Comparisons between different time points were analyzed using one-way ANOVA. AMS in the (C) control and CpG groups, (D) AP 3 h and CpG + AP $3 \mathrm{~h}$ groups, (E) AP $6 \mathrm{~h}$ and $\mathrm{CpG}+\mathrm{AP} 6 \mathrm{~h}$ groups and $(\mathrm{F}) \mathrm{AP} 12 \mathrm{~h}$ and $\mathrm{CpG}+\mathrm{AP} 12 \mathrm{~h}$ groups. Independent samples t-test was used for comparisons between two groups. ${ }^{\mathrm{P}}<0.05 \mathrm{vs}$. control group; ${ }^{\text {b }}<0.05$ vs. $3 \mathrm{~h}$ group; ${ }^{\mathrm{C}} \mathrm{P}<0.05$ vs. $6 \mathrm{~h}$ group; ${ }^{\mathrm{d}} \mathrm{P}<0.05$ vs. $\mathrm{CpG}$ group; ${ }^{\mathrm{e}} \mathrm{P}<0.05$ vs. AP group. AMS, serum amylase; AP, acute pancreatitis.

difference was identified among the AP 3, 6 and $12 \mathrm{~h}$ groups (P>0.05; Fig. 4A). Following treatment with $\mathrm{CpG}$, the tendency of AMS was the same as that in the AP groups (Fig. 4B). However, no significant change was observed between the AP and $\mathrm{CpG}+\mathrm{AP}$ groups at $0,3,6$, and $12 \mathrm{~h}$ (Fig. 4C-F).

\section{Discussion}

Significance of pathological, TLR9, TNF- $\alpha$ and serum AMS changes at different time points in AP rats. Pathological examination indicated that the severity of pancreatic tissue damage following AP increased over time. Additionally, TLR9 protein 
expression was upregulated subsequent to AP. TLR9 is a key determinant of the innate immune response in infectious and sterile injury (13). Previously, Hoque et al (2) demonstrated that host genomic DNA is markedly elevated in the blood very early in the course of experimental AP, which is consistent with a role for TLR9 in sensing initial pancreatic injury. In addition, serum DNA was demonstrated to be significantly elevated in patients with severe AP (SAP) (2). Furthermore, TLR9 was higher in $6 \mathrm{~h}$ than that in $3 \mathrm{~h}$. Zeng et al (7) also demonstrated that TLR9 was expressed in the pancreas of AP-induced rats and control animals. Furthermore, previous studies indicated that TLR9 is expressed by pancreatic ductal and endothelial cells (2), and resident immune cells (predominantly macrophages) (14). In the AP $3 \mathrm{~h}$ group in the present study, tissue samples presented a mild edema and RBCs were observed. In the AP $6 \mathrm{~h}$ group, certain pancreas samples also presented edema. Furthermore, certain cells were degenerated and more RBCs were observed when compared with that in the AP 3 h group. Xiang et al (15) indicated that chronic stress increases TLR9 expression levels in peritoneal macrophages and chronic stress promotes cell apoptosis via TLR9. When necrosis occurred in a large area of the pancreatic tissue, TLR9 expression levels were significantly decreased at $12 \mathrm{~h}$ compared with those at 3 and $6 \mathrm{~h}$, but were greater than those in the control group. Thus, these data indicate that TLR9 may be important in AP.

In addition, serum TNF- $\alpha$ protein levels and AMS were persistently increased from 3 until $12 \mathrm{~h}$ in rats subjected to AP. Expression levels of TNF- $\alpha$ protein at AP $12 \mathrm{~h}$ were higher than those in AP 3 and $6 \mathrm{~h}$. In addition, Wang et al (16) demonstrated that serum AMS activities and TNF- $\alpha$ expression levels significantly increased in the SAP group, when compared with the control group. Their data was consistent with the present results. In addition, previous studies indicated that higher expression levels of TNF- $\alpha$ were detected in mild AP and SAP mice at varying time points post induction $(14,17,18)$. Furthermore, during the pathogenic process of SAP, aberrant activation of inflammatory cells and excessive production of inflammatory mediators, such as TNF- $\alpha$ and IL- 6 causes pancreatic necrosis and systemic inflammatory response syndrome, as well as multiple organ dysfunction syndrome (17). In addition, the decrease in serum TNF- $\alpha$ expression levels in AP rats inhibits the inflammatory response to AP and exerts a significant protective effect on the pancreatic tissue and function in AP rats (14). Gomes et al (19) demonstrated that TLR9 is required for mitogen-activated protein kinase/nuclear factor- $\kappa \mathrm{B}$ activation, followed by IL-12 and TNF- $\alpha$ production. Thus, the serum TNF- $\alpha$ expression level may be associated with TLR9 activity in AP rats at 3 and $6 \mathrm{~h}$. At $12 \mathrm{~h}$, the serum TNF- $\alpha$ level was high; however, TLR9 protein expression was downregulated. To investigate the functions of TLR9, CpG-OND 1826 was employed.

Function of CpG-OND 1826 at different time points in AP rats. Krieg (20) demonstrated CpG-ODN to be a double-edged sword, as it may improve the host immune function; however, it may lead to autoimmune diseases. Thus, the function of CpG-ODN is complicated, and in order to investigate its function at different time points, AP model rats were used. The present data showed that TLR9 expression levels increased following CpG-OND administration. Furthermore, pancreatic injury was more serious in the $\mathrm{CpG}+\mathrm{AP}$ groups and the expression level of TNF- $\alpha$ was upregulated compared with that in the AP groups. Akira (21) demonstrated that TLR stimulation induces the innate immune response through the increased secretion of proinflammatory cytokines, such as TNF- $\alpha$, IL-1 $\beta$ and IL-6. However, Lee et al (14) indicated that simultaneous stimulation and restimulation of TLR7 and TLR9 with specific agonists induced tolerance in mouse macrophages, thereby reducing the production of proinflammatory cytokines, TNF- $\alpha$ and IL-6, when compared with individual stimulation. In addition, no significant difference was identified between the AP and $\mathrm{CpG}+\mathrm{AP}$ groups in ASM, and data indicated that there was no statistical correlation between the magnitude of the hyperamylasemia disease and the final outcome (22).

In conclusion, these data indicate that CpG-ODN1826 aggravates sodium taurocholate-induced AP in rats, which is accompanied by an increase of TLR 9 and TNF- $\alpha$ expression levels from 3 to $12 \mathrm{~h}$ following treatment. Therefore, the present results suggested that the downregulation of TLR9 and/or TNF- $\alpha$ protein levels may offer protection against pancreatic injury following AP.

\section{Acknowledgements}

The present study was supported by the Yunnan Provincial Science and Technology Department Foundation of China (grant no. 2015FB024).

\section{References}

1. Kim MJ, Bae GS, Jo IJ, Choi SB, Kim DG, Shin JY, Lee SK, Kim MJ, Shin S, Song HJ and Park SJ: Loganin protects against pancreatitis by inhibiting NF- $\kappa \mathrm{B}$ activation. Eur J Pharmacol 765: 541-550, 2015 .

2. Hoque R, Malik AF, Gorelick F and Mehal WZ: Sterile inflammatory response in acute pancreatitis. Pancreas 41: 353-357, 2012.

3. Weng TI, Wu HY, Chen BL, Jhuang JY, Huang KH, Chiang CK and Liu SH: C/EBP homologous protein deficiency aggravates acute pancreatitis and associated lung injury. World J Gastroenterol 19: 7097-7105, 2013.

4. Li J, Wu Y, Zhang S, Zhang J, Ji F, Bo W, Guo X and Li Z: Baicalein protect pancreatic injury in rats with severe acute pancreatitis by inhibiting pro-inflammatory cytokines expression. Biochem Biophys Res Commun 466: 664-669, 2015.

5. Ding JL, Zhou ZG, Zhou XY, Zhou B, Wang L, Wang R, Zhan L, Sun XF and Li Y: Attenuation of acute pancreatitis by peroxisome proliferator-activated receptor- $\alpha$ in rats: The effect on toll-like receptor signaling pathways. Pancreas 42: 114-122, 2013.

6. Shintani Y, Drexler HC, Kioka H, Terracciano CM, Coppen SR, Imamura H, Akao M, Nakai J, Wheeler AP, Higo S, et al: Toll-like receptor 9 protects non-immune cells from stress by modulating mitochondrial ATP synthesis through the inhibition of SERCA2. EMBO Rep 15: 438-445, 2014.

7. Zeng YJ, Song JM, Li Y, Wang R, Zhou B, Zhou ZG, Liu HY and Xu B: Toll-like receptor 9 is expressed in rat pancreas and is involved in cerulein-induced pancreatitis. Pancreas 36: 212-214, 2008.

8. Ma C, Spies NP, Gong T, Jones CX and Chu WM: Involvement of DNA-PKcs in the type I IFN response to CpG-ODNs in conventional dendritic cells in TLR9-dependent or -independent manners. PloS One 10: e0121371, 2015.

9. Yu C, Huang L, Li X, Zhu H, Li Z and Yu X: Spatial and temporal differences of HMGB1 expression in the pancreas of rats with acute pancreatitis. Int J Clin Exp Pathol 8: 6928-6935, 2015.

10. Han J, Xu X, Zhang B, Chen B and Hang W: Expression of ATF4 and RUNX2 in periodontal tissue of pressure side during orthodontic tooth movement in rat. Int J Clin Exp Med 8: 934-938, 2015. 
11. Schmidt J, Rattner DW, Lewandrowski K, Compton CC, Mandavilli U, Knoefel WT and Warshaw AL: A better model of acute pancreatitis for evaluating therapy. Ann Surg 215: 44-56, 1992.

12. Sholl LM, Sun H, Butaney M, Zhang C, Lee C, Jänne PA and Rodig SJ: ROS1 immunohistochemistry for detection of ROS1-rearranged lung adenocarcinomas. Am J Surg Pathol 37: 1441-1449, 2013.

13. Hoque R, Faroog A, Malik A, Trawick BN, Berberich DW, McClurg JP, Galen KP and Mehal W: A novel small-molecule enantiomeric analogue of traditional (-)-morphinans has specific TLR9 antagonist properties and reduces sterile inflammation-induced organ damage. J Immunol 190: 4297-4304, 2013.

14. Lee HJ, Kim KC, Han JA, Choi SS and Jung YJ: The early induction of suppressor of cy tokine signaling 1 and the downregulation of toll-like receptors 7 and 9 induce tolerance in costimulated macrophages. Mol Cells 38: 26-32, 2015.

15. Xiang Y, Yan H, Zhou J, Zhang Q, Hanley G, Caudle Y, LeSage $G$, Zhang $X$ and Yin D: The role of toll-like receptor 9 in chronic stress-induced apoptosis in macrophage. PloS One 10: e0123447, 2015.

16. Wang MM, Zhang T, Yang LH, Liu LW, Chen XC, Zhou MT and Chen BC: Sedum sarmentosun bunge extraction ameliorated severe acute pancreatitis-induced lung injury: An experimental research. Zhongguo Zhong Xi Yi Jie He Za Zhi 35: 228-233, 2015. (In Chinese)
17. Zhang X, Feng G, Weng W, Liang J, Lin N, Cai Y, Xu R, Zhou N, Yuan M, Yuan W and Xia X: Protective effects of baicalin and octreotide on intestinal mucosa of rats with severe acute pancreatitis. Turk J Gastroenterol 20: 108-115, 2009.

18. Xue QM, Pan H, Huang L and Li N: Effects of acupuncture at ST25 on inflammatory mediators and nuclear factor $\kappa \mathrm{B}$ activation in a rat model of severe acute pancreatitis. Acupunct Med 33: 299-304, 2015.

19. Gomes MT, Campos PC, Pereira Gde S, Bartholomeu DC, Splitter G and Oliveira SC: TLR9 is required for MAPK/NF-kB activation but does not cooperate with TLR2 or TLR6 to induce host resistance to Brucella abortus. J Leukoc Biol 99: 771-780, 2016.

20. Krieg AM: Therapeutic potential of toll-like receptor 9 activation. Nat Rev Drug Discov 5: 471-484, 2006.

21. Akira S: Innate immunity to pathogens: Diversity in receptors for microbial recognition. Immunol Rev 227: 5-8, 2009.

22. Vissers RJ, Abu-Laban RB and McHugh DF: Amylase and lipase in the emergency department evaluation of acute pancreatitis. J Emerg Med 17: 1027-1037, 1999.

(i) (2) This work is licensed under a Creative Commons Attribution-NonCommercial-NoDerivatives 4.0 International (CC BY-NC-ND 4.0) License. 